\title{
Pidana Seumur Hidup Dalam Sistem Pemasyarakatan
}

\author{
Diah Gustiniati Maulani
}

Dosen dan Ketua Bagian Pidana Fakultas Hukum Univ. Lampung

\begin{abstract}
Abstrak
Tujuan penelitian ini adalah untuk kebijakan pidana seumur hidup bila dihubungkan dengan system pemasyarakatan, dan perspektif pidana penjara seumur hidup dalam sistem pemasyarakatan. Berdasarkan telaah pustaka dan studi lapangan dapat disimpulkan bahwa pertama, sistem pemasyarakatan cenderung memberikan perlindungan individu dengan memberikan pembinaan sesuai dengan tahapan yang telah ditetapkan batas waktunya secara pasti yang tidak dapat dilaksanakan terhadap terpidana seumur hidup dengan batas waktu yang tidak pasti disamping itu pidana seumur hidup cenderung memberikan perlindungan masyarakat dengan mengabaikan perlidungan individu. Sehingga Kebijakan pidana seumur hidup dengan menggunakan sistem pemasyarakatan tidak sesuai atau tidak memenuhi tujuan pemidanaan. Kebijakan legislatif yang ada selama ini masih menempatkan pidana seumur hidup berada diluar system pemasyarakatan, sehingga eksistensi pidana seumur hidup dalam system pemasyarakatan perlu dipertanyakan karena tidak mempunyai dasar pembenaran yang kuat; dan kedua, pidana seumur hidup tetap dipertahankan karena tetap diperlukan terutama terhadap pelaku kejahatan berat sebagai upaya untuk melindungi masyarakat, namun keperluan untuk melindungi masyarakat tidak dimaksudkan untuk mengabaikan atau meniadakan perlindungan terhadap individu. Melainkan dalam keseimbangan yang layak perlindungan individu dan masyarakat.
\end{abstract}

Kata kunci : pidana seumur hidup, sistem pemasyarakatan

\section{PENDAHULUAN}

Bagian terpenting dalam suatu Kitab Undang-Undang Hukum Pidana (KUHP) adalah stelsel pidananya. Stelsel pidaana yang terdapat di dalam KUHP tersebut dapat dijadikan ukuran sampai seberapa jauh tingkat peradaban bangsa yang bersangkutan, karena stelsel pidana tersebut memuat aturan tentang jenis-jenis pidana dan juga memuat aturan tentang ukuran dan pelaksanaan dari pidana-pidana itu. Dari Jenis, ukuran dan cara pelaksanaannya itu dapat dinilai bagaimana sikap bangsa itu melalui pembentukan undang-undangnya dan pemerintahnya terhadap warga negaranya sendiri atau terhadap orang asing yang telah melakukan pelanggaran terhadap peraturan perundang-undangan pidana (Sudarto 1982:21).

Pidana penjara merupakan salah satu jenis pidana yang terdapat dalam stelsel pidana di Indonesia, sebagaimana terdapat dalam pasal 10 KUHP. Pidana penjara ini merupakan salah satu jenis pidana yang paling sering digunakan sebagai sarana untuk menanggulangi masalah 
kejahatan, sehingga pidana penjara disebut sebagai primadona dalam sistem sanksi pidana yang sering dijatuhkan oleh hakim dalam memutuskan perkara.

Berdasarkan ketentuan Pasal 12 KUHP, pidana penjara terdiri dari:

1. Pidana penjara seumur hidup

2. Pidana penjara selama waktu tertentu.

Pidana penjara selama waktu tertentu di dalam KUHP telah secara tegas memberikan batasan tentang jangka waktunya, yaitu maksimal lima belas tahun berturut-turut dan minimal satu hari, sedangkan KUHP tidak secara ekpslisit memberikan batasan tentang jangka waktu pidana penjara seumur hidup. Tidak adanya batasan pidana seumur hidup dalam KUHP seringkali menimbulkan kerancuan penafsiran dikalangan awam hukum.

Tujuan pidana seumur hidup hanya ditujukan untuk perlindungan masyarakat, sedangkan di dalam sistem pemasyarakatan tujuan pidana lebih berorientasi pada ide perlindungan dan pembinaan serta perbaikan (rehabilitasi) si terpidana untuk dikembalikan lagi ketengahtengah masyarakat, sehingga dalam hal ini ada kontradiksi ide antara pidana seumur hidup dengan sistem pemasyarakatan.

Keadan sebagaimana tersebut diatas ternyata tetap dipertahankan pidana penjara seumur hidup dalam sistem pemidanaan di Indonesia namun tidak berarti pidana seumur hidup telah diterima oleh masyarakat tanpa syarat. Banyak pihak yang merasa keberatan dengan tetap dipertahankannya pidana seumur hidup karena dianggap tidak sesuai dengan ide pemasyarakatan
Roeslan Saleh menyatakan bahwa dengan dijatuhkannya pidana penjara seumur hidup terpidana tidak lagi mempunyai harapan lagi kembali kemasyarakat tetapi harapan tersebut dapat dipulihkan dengan adanya lembaga grasi yang dapat merubah pidana penjara seumur hidup dngan pidana beberapa tahun. Biasanya dengan grasi pidana penjara seumur hidup dirubah menjadi dua puluh tahun. Kemudian apabila terpidana berkelakuan baik terus menerus maka setiap tanggal 17 Agustus tiap-tiap tahun terpidana dapat memperoleh remisi.(Roeslan Saleh, 1977:22)

Pidana seumur hidup yang merupakan perampasan kemerdekaan perlu mendapat perhatian karena selain tidak sesuai dengan ide pemasyarakatan, juga dalam hal ini terkait pula hak asasi manusia yang melekat pada diri terpidana . Oleh karena itu dalam hal pemberian dan pelaksanaan pidananya serta dalam memperlakukan mereka sebagai pelanggar hukum harus senantiasa dilandasi oleh prinsip-prinsip hakhak kemanusiaan, sebagaimana disebutkan oleh Soedarto tidak boleh sekali-sekali meninggalkan nilai-nilai kemanusiaan, ialah kasih sayang terhadap sesama (Barda Nawawi Arif, 1996:44).

Berdasarkan uraian tersebut, permasalahan yang hendak ditemukan jawabnya adalah bagaimanakah kebijakan pidana seumur hidup bila dihubungkan dengan system pemasyarakatan, dan perspektif pidana penjara seumur hidup dalam sistem pemasyarakatan.

\section{METODE PENELITIAN}

Pendekatan masalah yang digunakan adalah yuridis normatif 
dan empiris, sedangkan jenis dan sumber data adalah data sekunder. Prosedur pengumpulan data sekunder dengan studi kepustakaan dan studi lapangan guna memperoleh data primer.

\section{PEMBAHASAN}

\subsection{Pidana Penjara Seumur Hidup}

Pidana penjara adalah suatu pidana berupa pembatasan kebebasan bergerak dari seorang terpidana atau dengan kata lain berupa perampasan kemerdekaan seorang terpidana dalam waktu tertentu yang ditempatkan di Lembaga Pemasyarakatan (dahulu penjara).

Pidana penjara sebagai mana tersebut diatas dapat dijatuhkan seumur hidup atau untuk sementara waktu, sebagaimana disebutkan dalam Pasal 12 KUHP adalah sebagai berikut:

1. Pidana penjara ialah seumur hidup atau selama waktu tertentu

2. Pidana penjara selama waktu tertentu paling pendek satu hari dan paling lama lima belas tahun berturut-turut.

3. Pidana penjara selama waktu tertentu boleh di jaiuhkan untuk dua puluh tahun berturut-turut dalam hal kejahatan yang pidananya hakim boleh memilih antara pidana mati, pidana penjara seumur hidup, dan pidana penjara selama waktu tertentu atau antara pidana pidana penjara seumur hidup dan pidana penjara selama waktu tertentu, begitu juga dalam hal lima belas tahun dilampaui sebab tambahan pidana karena gabungan, pengulangan-pengulangan atas karena ditentukan Pasal 52 dan 52 a KUHP.
4. Pidana penjara selama waktu tertentu sekali-kali tidak boleh melebihi dua puluh tahun. (L. N 1958 No. 127)

Berdasarkan ketentuan Pasal 12 KUHP tersebut terlihat, bahwa pidana penjara selama waktu tertentu undang-undang/KUHP telah secara tegas memberikan batasan tentang jangka waktunya, yaitu maksimal lima belas tahun berturut-turut dan minimal satu hari.

Berbeda dengan jenis pidana penjara selama waktu tertentuyang secara eksplisit atau secara tegas ditentukan batas waktu antaranya, undang-undang (KUHP) tidak secara eksplisit memberikan batasan tentang jangka waktu pidana seumur hidup.

Tidak ada batasan tentang pidana seumur hidup dalam KUHP sering kali menimbulkan kerancuan penafsiran dikalangan awam hukum. Pengertian seumur hidup sering diartikan sama dengan umur (hidup) pelaku tindak pidana pada saat melakukan tindak pidana.

Pengertian yang berbeda tentang pidana sumur hidup lazim ditafsirkan sebagai pidana selama hidup atau sepanjang hidup, Barda Nawawi Arief, menyatakan bahwa

"Dilihat dari sudut penjatuhan pidana dan juga dari sudut terpidana, pidana seumur hidup itu bersifat pasti (definite sentence) karena siterpidana dikenakan jangka waktu yang pasti (a definite period of time) yaitu menjalani pidana penjara sepanjang hidupnya (Tongat, 2004: 37)

Karena sifatnya yang pasti itu, menurut Roeslan Saleh, orang menjadi keberatan terhadap pidana seumur hidup, sebab dengan putusan yang demikian terpidana tidak akan 
mempunyai harapan lagi kembali ke dalam masyarakat.

Dari pendapat kedua pakar hukum pidana sebagaimana tersebut di atas, dapatlah diketahui pidana penjara dalam hal seumur hidup, KUHP menganut sistem pidana yang ditentukan secara pasti (definite sentence), karena terpidana dikenakan jangka waktu tertentu yang pasti (a definite period of time), yaitu menjalani pidana sepanjang hidupnya.

\subsection{Sistem Pemasyarakatan}

Sistem pemasyarakatan merupakan sistem baru pengganti sistem penjara yang dilaksanakan di Indonesia sejak tahun 1964. Sistem pemasyarakatan ini berbeda dengan sistem kepenjaraan dimana tujuannya sistem pemasyarakatan adalah memasyarakatkan narapidana dengan memperlakukan narapidana sebagai manusia dan menjunjung tinggi martabat manusia. Hal ini sesuai dengan yang dikemukakan oleh Saharjo dalam pidatonya pada tanggal 5 Juli 1963 pada saat menerima gelar Doktor Honoris Causa Ilmu Hukum dari Unuversitas Indonesia, yang menyatakan bahwa:

Tiap orang adalah manusia dan harus diperlakukan sebagai manusia meskipun ia telah tersesat, tidak boleh selalu ditunjukkan pada narapidana bahwa ia penjahat, sebaliknya ia harus selalu merasa bahwa ia dipandang dan diperlakukan sebagai manusia.

Pelaksanaan sistem pemasyarakatan sebagai proses yang bersifat terpadu dilaksanakan melalui empat (4) tahap yaitu:

1. Tahap pertama (Maksimum Security). Pada tahap ini narapidana dijaga dengan ketat, yang dilaksanakan dari hari pertama narapidana mulai masuk sampai $1 / 3$ masa pidananya atau paling cepat satu bulan.

2. Tahap kedua (Medium Security). Tahap ini dilasanakan dari 1/3 samapai 1/2 masa pidananya. Pembinaan dilakukan di dalam lembaga pemasyarakatan.

3. Tahap ketiga (Minimum Security). Tahap ini sering disebut dengan tahap asimilasi yang dilaksanakan dari 1/2 sampai 2/3 masapidananya.

4. Tahap keempat (Integrasi). Pada tahap ini narapidana dapat diberikan haknya yaitu hak lepas bersyarat atau cuti menjelang bebas .

\subsection{Kebijakan Pidana Seumur Hidup Dalam Sistem Pemasyarakatan}

Sistem Pemasyarakatan adalah suatu tatanan mengenai arah dan batas serta cara pembinaan Warga Binaan Pemasyarakatan berdasarkan Pancasila yang dilaksanakan secara terpadu antara Pembina, yang dibina, dan masyarakat untuk meningkatkan kualitas Warga Binaan Pemasyarakatan agar menyadari kesalahan, memperbaiki diri dan tidak mengulangi tindak pidana sehingga dapat diterima kembali oleh lingkungan masyarakat, dapat aktif berperan dalam pembangunan, dan dan dapat hidup secara wajar sebagai waerga yang baik dan bertanggung jawab.

Memperhatikan apa yang menjadi rumusan dari sistem pemasyarakatan sebagaimana tersebut di atas beberapa hal yang yang perlu digaris bawahi adalah arah, batas serta cara dalam 
pembinaan, kemudian warga binaan pemasayarakatan dan tujuan dari pembinaan. Oleh karena itu hal-hal ini tentunya berhubungan dengan jenis pidana penjara yang dikenakan terhadap warga binaan pemasyarakatan, sehingga pembinaan yang dilakukan terhadap warga binaan pemasyarakatan dapat efektif. Tidak menjadi masalah apabila pembinaan tersebut dilakukan terhadap terpidana yang dikenakan pidana penjara selama waktu tertentu, oleh karena proses pemasyarakatan melalui empat (4) tahap baik berdasarkan pada keamanan (security) maupun tahap pembinaan yang telah ditetapkan batas-batas waktunya. Namun menjadi masalah apabila proses pemasarakatan melalui empat (4) tahap tersebut di terapkan terhadap terpidana seumur hidup (dalam waktu tidak tertentu) karena tidak dapat diketahui batas waktunya.

Dilihat dari kwalifikasinya, tindak pidana yang diancam dengan pidana seumur hidup adalah tindak pidana yang dikualifikasikan sebagai kejahatan berat. Tindak pidana tersebut terdapat di dalam Buku II KUHP yang tersebar dalam delapan (8) bab dan duapuluh tiga ketentuan, sebagaimana dapat dilihat pada Tabel 1 .

Tabel 1.

Kelompok Tindak Pidana yang diancam pidana seumur hidup dalam KUHP

\begin{tabular}{|c|c|}
\hline Kelompok Kejahatan & Pasal yang mengatur \\
\hline 1. Terhadap Keamanan Negara & $\begin{array}{l}\text { 104,106,107 (2), } 108(2), 11(2), 124 \\
(2), 124(3)\end{array}$ \\
\hline 2. Terhadap Negara & $140(3)$ \\
\hline $\begin{array}{l}\text { 3. Membahayakan Kepentingan } \\
\text { Umum }\end{array}$ & $\begin{array}{l}187 \mathrm{ke}-3,198 \mathrm{ke}-2,200 \mathrm{ke}-3,202 \\
(2), 204 \text { (2) }\end{array}$ \\
\hline 4. Terhadap Nyawa & 339,340 \\
\hline 5. Pencurian & $365(4)$ \\
\hline 6. Pemerasan dan Pengancaman & $368(2)$ \\
\hline 7. Pelayaran & 444 \\
\hline 8. Penerbangan & 479f sub b, $479 \mathrm{k}(1)(2), 479 \mathrm{o}(1)(2)$ \\
\hline
\end{tabular}

Berdasarkan tabel 1 di atas terlihat bahwa jenis kejahatan yang diancam pidana seumur hidup jumlahnya cukup besar yaitu ada 8 kelompok tindak pidana yaitu kelompok kejahatan terhadap keamanan negara terdapat 7 ketentuan yang memuat ancaman pidana seumur hidup, Kejahatan terhadap negara terdapat 1 ketentuan yang memuat ancaman pidana seumur hidup, kelompok kejahatan Membahayakan Kepentingan Umum tersebar dalam 7 pasal yang memuat ancaman pidana seumur hidup, kelompok kejahatan terhadap nyawa ada 2 Pasal yang memuat ancaman pidana seumur hidup, pencurian, kelompok pemerasan dan pengancaman, pelayaran masingmasing 1 pasal yang memuat ancaman seumur hidup dan penerbangan dimuat dalam 3 pasal yang memuat ancaman seumur hidup.

Perumusan ancaman pidana seumur hidup juga terdapat didalam perundang-undangan di luar KUHP, 
seperti Undang-undang Nomor 12 Tahun 1951 Tentang Senjata Api dan Bahan Peledak, UnadangUndang Tentang Narkotik, Undang-Undang Tentang Pemberantasa Tindak Pidana Korupsi, Undang-Undang Tentang Terorisme dan lain sebagainya.

Berdasarkan pada Tabel 1 dan Undang-Undang di luar KUHP tersebut menunjukkan begitu banyaknya tindak pidana yang diancam dengan pidana seumur hidup. Bila dihubungkan dengan pelaksanaan pidana, maka bagi mereka yang dikenakan pidana seumur hidup ditempatkan di lembaga pemasyarakatan dan kehidupan di dalamnya dikenakan dengan sistem pemasyarakatany yang dalam pelaksanaannya melalui suatu proses pemasyarakatan yang dilakukan melalui 4 tahap, yaitu:

1. Tahap Admisi dan Orientasi (maksimum security).

Tahap ini dijalankan sampai $1 / 3$ dari masa pidana yang sebanarnya;

2. Tahap Asimilasi dalam arti sempit (medium security). Tahap ini dilaksanakan dari 1/3 sampai 1/2 masapidana yang sebanrnya;

3. Tahap Asimilasi dalam arti luas (minimum security). Tahap ini dilaksanakan dari $1 / 2$ samapai 2/3 masa pidana yang sebenarnya

4. Tahap integrasi dilaksanakan dari 2/3 samapai bebas.

Melihat ketentuan tahapantahapan tersebut diatas tentunya tidak mungkin dapat diberlakukan kepada terpidana seumur hidup oleh karena lama pidana pada pidana seumur hidup tidak tertentu (tidak dapat diketahui batas waktunya). Tahapan yang harus dilalui sebagaimana tersebut diatas tidak dapat dilakukan, hal ini juga tentunya berhubungan dengan hak-hak dari terpidana karena hak-hak terpidana seperti cuti biasa, menjelang lepas mutlak (pre release), remisi, lepas bersyarat tidak diberlakukan (tidak dimiliki). Karena hak-hak tersebut berlaku (dapat dimiliki) sesuai pada tahap-tahap yang sedang dijalani.

Untuk memiliki hak-hak tersebut diatas bagi terpidana seumur hidup dimungkinkan yaitu dengan cara merubah pidana seumur hidup menjadi pidana sementara waktu melalui upaya hukum luar biasa, grasi. Bersarkan Pasal 9 Republik Indonesia Nomor 174 Tahun 1999 tentang Remisi, dinyatakan bahwa:

1. Narapidana yang dikenakan pidana penjara seumur hidup dan telah menjalani pidana paling sedikit lima (5) tahun berturutturut serta berkelakuan baik, dapat diubah pidananyamenjadi pidana penjara sementara, dengan lama sisa pidana yang masih harus dijalani paling lama 15 (lima belas) tahun;

2. Perubahan pidana penjara seumur hidup menjadi pidana sementara sebagaimana dimaksud dalam ayat satu (1) ditetapkan dengan keputusan Presiden;

3. Permohonan perubahan pidana penjara seumur hidup menjadi pidana penjara sementara diajukan narapidana yang bersangkutan kepada presiden melalu Menteri Hukum dan Perundang-undangan (Dalam Kabinet Indonesia Bersatu, 2004 disebut Menteri Hukum dan Hak Asasi Manusia)

Hak-hak sebagaimana tersebut di atas bagi terpidana seumur hidup tidak mudah untuk mendapatkannya, oleh karena banyaknya faktor 
penghambat yang bersifat yuridis yang dihadapi.

Berbagai faktor penghambat yang bersifat yuridis tersebut antara lain:

1. Ketentuan yang terdapat dalam KUHP.

Misalnya tidak adanya ketentuan dalam KUHP yang memberikan kemungkinan terpidana seumur hidup melakukan readaptasi social. Sekalipun Pasal 15 (1) KUHP tentang pelepasan bersyarat bagi terpidana seumur hidup dimungkinkan, sebagai bentuk "pembinaan dalam masyarakat" tetapi ketentuan tersebut sangat sulit diterapkan bagi terpidana seumur hidup. Oleh karena terpidana seumur hidup batas waktu pidananya tidak dapat ditentukan, sedangkan Pasal 15 (1) KUHP tampaknya hanya diberikan kepada terpidana yang batas waktu pidanya dapat diketahui atau dapat diukur. Ketentua pasal tersebut yaitu "jika terpidana telah menjalani 2/3 dari lamanya pidana penjara yang dijatuhkan kepadanya atau yang sekurang-kurangnya sembilan bulan, maka kepadanya dapat diberikan pelepasan bersyarat. Jika terpidana harus menjalai beberapa pidana berturut-turut, pidana itu dianggap sebagai satu pidana.

Ketentuan Pasal 15 (1) KUHP ini terlihat bahwa, pelepasan bersyarat akan diberikan kepada narapidana setelah yang bersangkutan menjalani $2 / 3$ dari pidana yang dijatuhkan.

Berdasarkan pada ketentuan ini berarti terpidana seumur hidup tidak bisa diberikan pelepasan bersyarat sebab dengan tidak diketahuinya batas waktu pidana seumur hidup, maka tidak dapat ditentukan dua pertiga (2/3) dari pidana seumur hidup.

2. Ketentuan Pasal 1 (1) Keppres 5/1987 dinyatakan "setiap narapidana yang menjalani pidana penjara sementara diberikan pengurangan masa menjalani pidana apabila selama menjalani pidana ia berkelakuan baik"

Berdasarkan ketentuan tersebut, pelepasan bersyarat diberikan dengan dua persyaratanya itu:

1. pidanya harus berupa pidana penjara selama waktu tertentu (sementara)

2. selama menjalani pidana, narapidana berkelakuan baik

Dengan persyaratan yang ditentukan dalam nomor 1 di atas jelas tidak memberikan kemungkinan bagi terpidana seumur hidup untuk memperoleh remisi. Kemungkinan untuk memperoleh remisi bagi terpidana seumur hidup apabila syarat pidananya telah diubah dari pidana seumur hidup menjadi pidana penjara selama waktu tertentu. Hal ini diatur dalam pasal 7 (2) Keppres 5/1987, yaitu: "perubahan pidana penjara seumur hidup menjadi pidana penjara sementara dilakukan oleh presiden" Dengan demikian pidana seumur hidup hanya dapat berubah menjadi pidana selama waktu tertentu melalui grasi.

3. Ketentuan Peraturan Menteri Kehakiman No. M. 03.HM.02.02 tahun 1988 dan Keputusan Menteri Kehakiman Nomor 
M.01.PR.04.10 tahun 1989 yang menyatakan bahwa persyaratan subtantif bagi seorang narapidana untuk dapat ijin asimilasi antara lain telah menjalani $1 / 2$ dari masa pidananya, dari ketentuan ini juga asimilasi tidak mungkin diberikan kepada terpidana seumur hidup, oleh karena tidak dapat ditentukan $1 / 2$ dari masa pidananya.

Bertolak pada hal tersebut diatas, tampaknya terpidana seumur hidup tidak dapat menjalankan proses pemasyarakatan sebagaimana telah ditetapkan.

Bila ditinjau keberadaan pidana seumur hidup dengan mengingat sifat atau karakternya yang indeterminate (Barda Nawawi Arif, 2002:237) karena tidak tahu pasti jangka waktunya maka sebenarnya ada kontradiksi ide antara pidana seumur hidup dengan system pemasyarakatan.

Jadi dilihat dari ide pemasyarakatan pada hakekatnya pidana perampasan kemerdekaan seseorang hanya bersifat sementara (untuk waktu tertentu) tidak untuk seumur hidup (untuk waktu yang tidak ditentukan).

Pidana seumur hidup yang dijatuhkan kepada seseorang mempunyai tujuan tertentu, sebagaiman tujuan itu harus ditetapkan karena merupakan prasayarat bagi suatu politik criminal yang rasional, sebagaimana dikemukakan Karl O. Christiansen sebagai berikut:

"Prasyarat yang fundamental dalam merumuskan suatu cara, metode atau tindakan yang rasional ialah bahwa tujuan yang akan dicapai telah dirumuskan dengan baik..."
Berdasarkan pada pendapat tersebut maka untuk melihat dasar pembenaran pidana seumur hidup dalam sistem hukum pidana di Indonesia akan dilihat apakah pidana seumur hidup yang ada dalam perundang-undangan di Indonesia (KUHP dan UU lain) dapat memenuhi tujuan pemidanaan yang telah ditetapkan dalam sistem pemasyarakatan di Indonesia.

Dalam hal ini juga terjadi kontradiksi antara tujuan pidana seumur hidup dengan tujuan system pemasyarakatan. Masing-masing tujuan berdasarkan pada berbagai teori pemidanaan, pada intinya aspek pokok tujuan pemidanaan adalah :

1. Aspek perlindungan masyarakat

2. Aspek perlindungan terhadap individu.

Melihat kedua aspek tujuan pemidanaan ini, pada pidana seumur hidup tujuan pemidanaan berorientasi pada perlindungan masyarakat. Karena Pada hakekatnya pidana seumur hidup merupakan perampasan kemerdekaan sepanjang hidup terpidana. Ini berarti pembatasan ruang gerak terpidana untuk melakukan kejahatan. Berarti selama itu pula masyarakat merasa aman dan terlindungi dari gangguan jahat terpidana. Dilihat dari unsure perlindungan masyarakat, kebijakan tentang pidana seumur hidup yang ada dalam perundang-undangan di Indonesia dapat dikatakan memenuhi atau sesuai dengan aspek perlindungan masyarakat.

Selanjutnya kebijakan pidana seumur hidup dilihat dari system pemasyarakatan bahwa system pemasyarakatan mengandung aspek perlindungan individu, karena tujuannya antara lain;

1. Membina terpidana untuk tidak melanggar hokum 
2. Terpidana kembali hidup di tengah-tengah masyarakat dan berperan aktif dalam pembangunan

3. Menghilangkan rasa bersalah, hidup bahagia dunia dan akhirat

Aspek perlindungan individu ini merupakan implementasi dari falsafah pembinaan sebagai falsafah pemidanaan yang sekarang dianut.

Berdasarkan konsep tersebut, maka resosialisasi terpidana merupakan tujuan utama dari pidana penjara, ini menunjukkan sistem pemasyarakatan tujuannya lebih berorientasi pada perlindungan individu.

Kebijakan tentang pidana seumur hidup yang ada dalam perundang-undangan Indonesia telah menempatkan terpidana dalam penderitaan akibat pencabutan kemerdekaan sepanjang hidupnya. Disini tampak pidana seumur hidup dalam sistem pemasyarakatan tidak dapat memainkan fungsinya sebagai "alat" untuk mempersiapkan terpidana melakukan resosialisasi terpidana yang justru merupakan tujuan utama pidana penjara dengan sistem pemasyarakatan.

Berdasarkan pada uraian tersebut diatas bila dilihat dari aspek perlindungan individu, kebijakan tentang pidana seumur hidup dengan menggunakan sistem pemasyarakatn dapat dikatakan tidak sesuai atau tidak memenuhi tujuan pemidanaan. Sistem pemasyarakatan cenderung memberikan perlindungan individu yang tidak dapat dilaksanakan terhadap terpidana seumur hidup dengan alasan terpidana seumur hidup dilaksanakan di dalam lembaga pemasyarakatan dengan tanpa batas waktu yang pasti. Selain itu pidana seumur hidup cenderung memberikan

perlindungan masyarakat dengan mengabaikan perlidungan individu.

Lebih lanjut dapat diketahui bahwa berdasarkan pada teori pemidanaan yang integratif, kebijakan pidana seumur hidup dengan pelaksanaannya menggunakan sistem pemasyarakatan tidak dapat dibenarkan karena tidak dapat memberikan perlindungan kepada individu dan masyarakat secara integratif.

Berdasarkan pada uraian tersebut diatas dapat dikatakan bahwa kebijakan legislatif yang ada selama ini masih menempatkan pidana seumur hidup berada diluar system pemasyarakatan, sehingga eksistensi pidana seumur hidup dalam system pemasyarakatan perlu dipertanyakan karena tidak mempunyai dasar pembenaran yang kuat.

\subsection{Perspektip Pidana Seumur Hidup Dalam sistem Pemasyarakatan}

Secara doktrinal, pidana seumur hidup lazim ditafsirkan sebagai pidana selama hidup atau sepanjang hidup.

Berdasarkan penelusuran sejarah sistem pidana dan pemidanaan dari jaman Majapahit tidak mencatat adanya pidana penjara, termasuk didalamnya pidana seumur hidup. Pidana penjara baru dikenal ketika VOC (Verenigde Oast Indische Compagnie) memperkenalkan lembaga bui pada tahun 1602 yang kemudian dilanjutkan jaman Hindia Belanda menjadi Pidana penjara. Keberadaan pidana penjara semakin eksis dalam sisti hukum pidana di Indonesia dengan adanya unifikasi WVS (Wetbook van 
Strafrecht) di Indonesia dengan Stb. 1915-732 yang mulai berlaku 1 Januari 1918. Dengan diberlakukannya WVS di Indonesia maka secara resmi pidana penjara termasuk pidana seumur hidup menjadi salah satu jenis pidana yang ada dalam sistem hukum pidana di Indonesia.

Berdasarkan uraian tersebut tampaklah bahwa, pidana penjara termasuk pidana seumur hidup merupakan produk hukum barat, bukan produk asli bangsa Indonesia dan karenanya tidak berasal dari nilai-nilai yang hidup dalam masyarakat Indonesia.

$$
\text { Kebijakan tentang pidana }
$$

seumur hidup dalam sistem perundang-undangan pidana di Indonesia yang ada selama ini belum mengimplementasikan gagasan atau ide monodualistik sebagai nilai-nilai dasar dalam masyarakat Indonesia. Belum diimplementasikannya nilainilai monodualistik dalam pidana seumur hidup tersebut telah menjadikan pidana seumur hidup dalam kebijakan legislatif di Indonesia tidak dapat memberikan keseimbangan perlindungan terhadap individu dan kepada masyarakat. .

Ketidakmampuan pidana seumur hidup memberikan perlindungan yang integratif kepada individu dan masyarakat nampak dari kenyataan seperti berikut:

1. Kebijakan tentang pidana seumur hidup dalam perundangundangan pidana di Indonesia baik yang ada di dalam KUHP maupun dalam undang-undang di luar KUHP termasuk dalam ketentuan atau aturan pelaksananya cenderung hanya diorientasikan pada perlindungan masyarakat sebagai refleksi atas fungsi pidana sebagai sarana pencegahan kejahatan.
2. Kebijakan tentang pidana seumur hidup dalam perundangundangan di Indonesia tidak memberikan kemungkinan modifikasi atas pertimbangan adanya perubahan atau perbaikan pada diri pelaku tindak pidana selama menjalani pidananya.

Kebijakan pidana seumur hidup dalam perundang-undangan di Indonesia dalam pelaksanaanya menjadi kontradiksi dengan sistem pemasyarakatan sebagai sistem pelaksanaan pidana penjara.

Sistem pemasyarakatan yang dianut oleh Indonesia, diatur dalam Undang-undang Nomor 12 Tahun 1995 merupakan perubahan ide secara yuridis filosofis dari sistem kepenjaraan menjadi sistem pemasyarakatan yang lebih berorientasi pada ide perlindungan atau pembinaan dan perbaikan atau rehabilitasi terpidana untuk dikembalikan lagi ketengah-tengah masyarakat dan dalam melakukan pembinaan dan perbaikan atau rehabilitasi tersebut digunakan tahapan berdasarkan pada jangka waktu yang pasti. Dengan demikian berarti pidana seumur hidup tidak dapat dilaksanakan dengan sistem pemasyarakatan oleh karena pidana seumur hidup tidak ada jangka waktu yang pasti, disamping itu pidana seumur hidup lebih berorientasi pada ide perlindungan masyarakat, sementara aspek perlindungan individu kurang diperhatikan. Sehingga tampak jelas tidak adanya keseimbangan perlindungan antara kepentingan individu dan kepentingan masyarakat.

Sebagai salah satu jenis pidana yang terdapat dalam perundangundangan pidana di Indonesia, kebijakan pidana seumur hidup yang terumus dalam KUHP tidak 
memberikan kemungkinan

"modifikasi atau perubahan/

penyesuaian/peninjauan kembali

putusan pidana yang telah

berkekuatan tetap" yang didasarkan

pertimbangan karena adanya

"perubahan/perkemabanga/perbaikan

pada diri terpidana itu sendiri".

Dengan demikian dapatlah diketahui

bahwa kebijakan tentang pidana seumur hidup yang ada dalam KUHP sekarang kurang berorientasi pada ide "individualisasi pidana". Sehingga terdapat kesenjangan antara yang seharusnya dengan keadaan yang senyatanya.

Sebagai negara yang

berdasarkan Pancasila sudah seharusnya dalam menetapkan kebijakan berbangsa dan bernegara khususnya dibidang hukum Pancasila dijadikan sebagai dasar atau landasan. Sehingga ide/nilai monodualistik atau keseimbangan menjiwai setiap kebijakan legislatif termasuk kebijakan pidana seumur hidup. Dengan demikian pidana seumur hidup tetap dipertahankan karena tetap diperlukan terutaama terhadap pelaku kejahatan berat sebagai upaya untuk melindungi masyarakat, namun keperluan untuk melindungi masyarakat itu tidak dimaksudkan untuk mengabaikan atau meniadakan perlindungan terhadap individu. Dalam keseimbangan yang layak perlindungan individu dan masyarakat dalam pidana penjara harus terumuskan. Oleh karena dengan perlindungan yang integratif, pidana penjara tetap diakui eksistensinya dan karenanya memperoleh pembenaran.

Berdasarkan pada uraian tersebut diatas dapatlah diketahui, bahwa keseimbangan perlindungan antara individu dan masyarakat dalam pidana penjara termasuk pidana seumur hidup yang dilakanakan dengan sistem pemasyarakartan bukan saja merupakan keharusan dalam sistem hukum pidana di Indonesia oleh karena tuntutan nilai-nilai dalam masyarakat, tetapi juga merupakan kecenderungan atau trend yang sedang berkembang dalam masyarakat internasional

Lebih lanjut juga dapat diketahui urgensi mengimplementasikan ide monodualistik pada pidana seumur hidup yang dilaksanakan dakam sistem pemasyarakatan dalam upaya agar pidana seumur hidup memberikan perlindungan yang seimbang kepada individu dan masyarakat sesuai dengan nilai-nilai yang berkembang pada masyarakat Indonesia dan masyarakat internasional.

Melihat kebijakan pidana seumur hidup yang ada dalam perundang-undangan pidana di Indonesia selama ini tidak dapat menunjang aspek perlindungan individu maka sangat mendesak untuk dipertimbangkan dan disusun kembali adalah berkaitan dengan ketentuan tentang adanya kemungkinan "modifikasi/perubahan/penyesuaian kembali putusan pemidanaan yang telah berkekuatan hukum tetap" yang didasarkan karena adanya "perubahan/perkembangan/perbaikan pada diri terpidana itu sendiri".

Hal ini di dalam Konsep Rancangan KUHP baru telah dirumuskan adanya kemungkinan modifikasi/perubahan sebagaimana dinyakan dalam Pasal 63 (5) yang menyatakan :

"Apabila terpidana seumur hidup telah menjalani pidana sekuran-kurangnya 10 tahun 
pertama dengan berkelakuan baik, mak Menteri Kehakiman, atas usul kepala lembaga pemasyarakatan dimana terpidana menjalani pidananya, dapat merubah sisa pidana penjara seumur hidup menjadi pidana paling lama 15 tahun."

Berdasarkan pada ketentuan tersebut diatas dapat diketahui bahwa terpidana seumur hidup tetap diberi kesempatan untuk kembali kedalam masyarakat, dengan syarat, dalam 10 tahun pertama menjalani pidananya berkelakuan baik.

Tampaknya Pasal tersebut diatas belum sepenuhnya mengimplementasikan gagasan/ide monodualistik, tetapi adanya rumusan pasal tersebut diatas menunjukkan, bahwa perlindungan terhadap individu dalam pidana seumur hidup mulai diperhatikan.

Adanya kebijakan tentang pidana seumur hidup yang memberikan kemungkinan modifikasi terhadap putusan pemidanaan yang telah berkekuatan hukum tetap jelas akan sangat menunjang aspek pokok tujuan pemidanaan baik yang bersifat individu maupun sosial. Dengan kata lain dapat dikemukakan bahwa kebijakan yang demikian dapat memberikan "keseimbangan" perlindungan terhadap individu dan masyarakat.

Dengan adanya kebijakan memberikan kemungkinan modifikasi terhadap pidana seumur hidup, diharapkan pidana seumur hidup benar-benar dapat memberikan perlindungan terhadap induividu dan masyarakat secara integratif, dengan begitu pidana seumur hidup dapat tetap dipertahankan tanpa harus kehilangan dasar pembenarannya.

\section{PENUTUP}

\subsection{Simpulan.}

1. Sistem cenderung pemasyarakatan memberikan perlindungan individu dengan memberikan pembinaan sesuai dengan tahapan yang telah ditetapkan batas waktunya secara pasti yang tidak dapat dilaksanakan terhadap terpidana seumur hidup dengan batas waktu yang tidak pasti disamping itu pidana seumur hidup cenderung memberikan perlindungan masyarakat dengan mengabaikan perlidungan individu. Sehingga Kebijakan pidana seumur hidup dengan menggunakan sistem pemasyarakatan tidak sesuai atau tidak memenuhi tujuan pemidanaan. Kebijakan legislatif yang ada selama ini masih menempatkan pidana seumur hidup berada diluar system pemasyarakatan, sehingga eksistensi pidana seumur hidup dalam system pemasyarakatan perlu dipertanyakan karena tidak mempunyai dasar pembenaran yang kuat.

2. Pidana seumur hidup tetap dipertahankan karena tetap diperlukan terutama terhadap pelaku kejahatan berat sebagai upaya untuk melindungi masyarakat, namun keperluan untuk melindungi masyarakat tidak dimaksudkan untuk mengabaikan atau meniadakan perlindungan terhadap individu. Melainkan dalam keseimbangan yang layak perlindungan individu dan masyarakat. 


\subsection{Saran}

1. Kebijakan pidana seumur hidup dengan menggunakan sistem pemasyarakatan tetap dipertahankan dengan tidak mengenyampingkan pembinaan melaui pendekatan keamanan tanpa melalui tahapan-tahapan sesuai dengan batas waktu yang telah ditetapkan.

2. Penjatuhan pidana seumur hidup harus menganut ide monodualistik sehinga tujuan penjatuhan pidana seumur hidup dengan pelaksanaannya menggunakan sistem pemasyarakatan tujuannya tercapai selain perlindungan terhadap masyarakat juga perlindungan terhadap individu (terpidana).

\section{DAFTAR PUSTAKA}

Arif, Barda Nawawi, 2001, Masalah Penegakan Hukum dan Kebijakan Penanggulangan Kejahatan, Citra Aditya Bakti, Bandung.

,2002, Bunga Rampai Kebijakan Hukum Pidana, Citra Aditya Bakti, Bandung.

Dipradja, R. Achmad S Soema dan Romli Atmasasmita, 1979, Sistem Pemasyarakatan di Indonesia, Bina Cipta, Bandung.
Hamzah, Andi, 2005, Azas-Azas Hukum Pidana, PT. Yarsif Watampone, Jakarta.

Lamintang, P.A.F, 1994, Hukum Penitensier Indonesia, Armico, Bandung.

Muladi, 1985, Lembaga Pidana Bersyarat, Alumni, Bandung.

Priyatno, Dwidja, 2006, Sistem Pelaksanaan Pidana Penjara di Indonesia, PT. Refika Aditama, Bandung.

Prodjodikoro, Wirjono, 1989, AzasAzas Hukum Pidana di Indonesia, Eresco, Bandung.

Poernomo, Bambang, 1986, Pelaksanaan Pidana Penjara Dengan Sistem Pemasyarakatan, Liberty, Yogyakarta.

Soejono, 1996, Kejahatan Dan Penegakan Hukum di Indonesia, Rineka Cipta, Jakarta.

Soekanto, Soerjono, 1986, Pengantar Penelitian Hukum, UI Press, Jakarta.

Soedarto, 1981 Hukum Dan Hukum Pidana, Alumni, Bandung

,1986, Kapita Selekta Hukum Pidana, Alumni, Bandung.

Undang-Undang Nomor 12 Tahun 1995 Tentang Pemasyarakatan

Tongat, 2004, Pidana Seumur Hidup, UMM Press, Malang.

Kitab Undang-Undang Hukum Pidana 